\title{
AKTIVITAS LARVASIDA EKSTRAK METANOL BUAH PARE (Momordica charantia L.) TERHADAP LARVA Aedes aegypti
}

\section{LARVICIDAL ACTIVITY OF BITTER MELON FRUIT METHANOL EXTRACT AGAINST LARVAE OF Aedes aegypti}

\author{
Susilawati $^{1}$ dan Hermansyah ${ }^{2 *}$ \\ ${ }^{1}$ Fakultas Kedokteran Universitas Sriwijaya \\ ${ }^{2}$ Jurusan Kimia FMIPA Universitas Sriwijaya \\ Email : susilwt78@yahoo.com
}

\begin{abstract}
ABSTRAK
Demam berdarah masih menjadi salah satu penyakit endemis dan masalah kesehatan utama di Indonesia. Buah pare (Momordica charantia L.) secara tradisional sering digunakan sebagai obat. Tujuan dari penelitian ini adalah untuk mengetahui efektifitas larvasida ekstrak metanol buah pare (Momordica charantia L.) terhadap larva Aedes aegypti dan mengetahui nilai $\mathrm{LC}_{50}$. Buah pare diekstrak dengan metode maserasi menggunakan pelarut metanol. Uji efektifitas larvasida dilakukan dengan menghitung jumlah larva uji yang mati setelah terpapar ekstrak buah pare dalam waktu tertentu. Berdasarkan hasil pengujian, sampel ekstrak metanol buah pare memiliki aktivitas larvasida terhadap larva Aedes aegypti. Nilai $\mathrm{LC}_{50}$ ekstrak metanol buah pare untuk tiap waktu pajanan berbeda.
\end{abstract}

Kata Kunci: Demam Berdarah, larva, Aedes aegypti, Momordica charantia, LC50.

\begin{abstract}
Dengue hemorrhagic fever is one of the endemic disease and the main health problem in Indonesia. Bitter melon fruit (Momordica charantia L.) was traditionally used as a medicine. The aim of this research was to know larvicidal activity of bitter melon fruit methanol extract against larvae of Aedes aegypti and to know its $\mathrm{LC}_{50}$ value. Bitter melon fruit was extracted by maceration method using methanol as a solvent. The larvicidal activity assay was carried out by calculating the amount dead of larvae after exposure with bitter melon fruit methanol extract in certain time period. Based upon the results, bitter melon fruit methanol extract had larvicidal activity against Aedes aegypti. $\mathrm{LC}_{50}$ value of bitter melon fruit methanol extract is different for different exposures.
\end{abstract}

Key words: Dengue hemorrhagic fever, larvae, Aedes aegypti, Momordica charantia, $\mathrm{LC}_{50}$.

\section{PENDAHULUAN}

Penyakit demam berdarah dengue (DBD) atau dengue hemorrhagic fever (DHF) menjadi permasalahan kesehatan masyarakat perlu mendapat perhatian serius. Penyakit yang tersebar ke seluruh provinsi di Indonesia, awalnya masuk melalui pelabuhan Surabaya (Natadisastra dan Agus, 2009). Pada tahun 2012, penderita demam berdarah sebanyak 90.245 orang dengan jumlah kematian 816 orang. Terdapat 14 kabupaten/kota dari delapan provinsi yang melaporkan terjadinya kejadian luar biasa. Jumlah ini meningkat $11 \%$ dibanding tahun 
sebelumnya 2011. (Kemenkes RI, 2012). Sedangkan di kota Palembang jumlah penderita DBD pada tahun 2012 tersebut sebanyak 883 orang dengan incidence rate 57,97 (Dinkes kota Palembang, 2012)

Aedes aegypti (A. Aegypti) merupakan vector utama penyakit DBD. Nyamuk $A$. aegypti umumnya memiliki habitat di lingkungan perumahan, di mana terdapat banyak genangan air bersih dalam bak mandi ataupun tempayan. Oleh karena itu, jenis ini bersifat urban. Ada hubungan antara keberadaan jentik Aedes aegypti pada tempat penampungan air, menguras tempat penampungan air, dan penggunaan obat anti nyamuk siang-malam dengan kejadian DBD (Tamza dkk 2013). Dengan demikian, pengendalian DBD dilakukan dengan memutus rantai penularan vector baik secara kimia dengan penyemprotan insektisida, penggunaan abate dan temephos, secara biologi menggunakan predator ataupun bakteri, dan juga secara fisik dengan menerapkan manajemen lingkungan bersih.

Kandungan senyawa bioaktif dalam buah pare ( $M$. charantia L.) telah banyak dieksplor, diantaranya delapan senyawa dilaporkan oleh Li et. al. (2009) yaitu : 1) momordicolide ((10E)-3-hydroxyl-dodeca10-en-9-olide, 2) monordicophenoide A (4-hydroxyl-benzoic acid 4-O-beta-Dapiofuranosyl $(1 \rightarrow$ 2)-O-beta-Dglucopyranoside, 3) dihydrophaseic acid 3O-beta-D-glucopyranoside, 4) 6,9dihydroxy-megastigman-4,7-dien-3-one (blumenol), 5) guanosine, 6) adenosine, 7) uracil dan 8) cytosine. Senyawa lainnya mengandung glikosida triterpen jenis cucurbitane (Yen at. al., 2014), triterpenoid jenis oleanane (Popovich et. al, 2010). Ekstrak metanol daun buah pare maupun buah pare menunjukkan aktivitas larvasida yang efektif (Rahuman dan Venkatesan, 2008; Li et. al., 2012).

Penelitian ini bertujuan untuk mengetahui efektifitas larvasida ekstrak metanol buah pare (M. charantia L.) terhadap larva Aedes aegypti dan mengetahui nilai LC $_{50}$ ekstrak metanol buah pare yang paling berpotensi digunakan sebagai biolarvasida terhadap larva Aedes aegypti. Hasil penelitian ini diharapkan dapat memberikan informasi kepada masyarakat tentang kegunaan dari buah pare yang dapat digunakan sebagai larvasida nyamuk vektor virus demam berdarah. Penggunaaan biolarvasida akan mengurangi dampak negatif isektisida terhadap lingkungan.

\section{METODOLOGI}

\section{Bahan}

Larva Aedes aegypti instar III, buah pare (M. charantia L.), metanol, DMSO.

\section{Prosedur Penelitian}

Persiapan ekstrak metanol buah pare dilakukan di laboratorium Biokimia FMIPA Universitas Sriwijaya, sedangkan pengujian aktivitas larvasida dilakukan di Balai Besar Laboratorium Kesehatan Batu Raja.

\section{Persiapan sampel}

Sebanyak $10 \mathrm{~kg}$ buah pare (M.charantia L) mentah yang dibeli dari pasar KM5 dibersihkan dari kontaminasi lain, dicuci, dipotong kecil-kecil, dan dikeringkan dengan cara diangin-anginkan untuk menghilangkan kadar air hingga didapat berat konstan. Selanjutnya dihaluskan hingga berukuran 100 mesh.

\section{Pembuatan ekstrak metanol buah pare secara maserasi}

Lima ratus gram serbuk kering buah pare (M.charantia L) dimaserasi dengan 1000 mL metanol selama 24 jam, sambil diadukaduk secara berkala, disaring. Ampas sisa dimaserasi lagi 3 kali supaya semua zat yang terkandung dalam buah pare tersebut terekstrak. Semua filtrat yang selanjutnya dikumpulkan dan dievaporasi pelarut metanol dengan suhu 60 derajat hingga didapat ekstrak buah pare. 
Persiapan larutan uji yang mengandung ekstrak buah pare

Buat larutan stok dengan konsentrasi 25 $\mathrm{mg} / \mathrm{mL}$ dengan cara melarutkan sebanyak $5 \mathrm{mg}$ ekstrak buah pare ke dalam DMSO sampai volume $200 \mu \mathrm{L}$. Larutan stok kemudian diencerkan hingga didapat konsentrasi $0,5 \mu \mathrm{g} / \mathrm{mL}$ dengan cara mengencerkannya menggunakan media RPMI (Roswell Park Memorial Institute) 1640.

\section{Uji larvasida terhadap Aedes aegypti}

Ekstrak metanol buah pare yang didapat siap dilakukan uji larvasida terhadap larva nyamuk Aedes aegypti. Konsentrasi ekstrak metanol dibuat 0,$125 ; 0,250 ; 0,5$; 1,0; dan $2 \mathrm{mg} / \mathrm{mL}$. Sepanjang perlakuan suhu berkisar $26-27{ }^{0} \mathrm{C}$ dan kelembaban udara $70 \%$, dengan waktu pengamatan 0,5 ;
$1 ; 1,5 ; 2 ; 3 ; 4 ; 5 ; 10 ; 20 ; 24 ; 26 ; 28 ; 30 ; 35$; dan 48 jam. Berdasarkan data persentase kematian larva dilakukan analisis antara konsentrasi uji terhadap persen kematian larva dengan menggunakan analisis probit $\log$ untuk mengetahui $\mathrm{LC}_{50}$ atau konsentrasi bahan uji yang dapat menyebabkan kematian larva sebanyak $50 \%$.

\section{HASIL DAN PEMBAHASAN}

Buah pare yang telah diekstrak dengan metanol, kemudian dilakukan evaporasi metanol sehingga didapatkan ekstrak metanol buah pare sebanyak 47 gram yang siap dilakukan uji larvasida terhadap larva Aedes aegypti. Persentase kematian larva Aedes aegypti dalam berbagai dosis ekstrak metanol buah pare dengan 4 kali pengulangan dapat dilihat pada Tabel 1.

Tabel 1. Persentase kematian Aedes aegypti dalam berbagai dosis ekstrak metanol buah pare.

\begin{tabular}{ccccccc}
\hline & $\begin{array}{c}\text { Abate } \\
\mathbf{1 0 \% / 1 0 m L}\end{array}$ & $\begin{array}{c}\text { Ekstrak } \\
\text { Pare } \\
\mathbf{0 , 1 2 5} \mathbf{m g} / \mathbf{m L}\end{array}$ & $\begin{array}{c}\text { Ekstrak } \\
\text { pare } \\
\mathbf{0 , 2 5 m g / m L}\end{array}$ & $\begin{array}{c}\text { Ekstrak } \\
\text { pare } \\
\mathbf{0 , 5 m g} / \mathbf{m L}\end{array}$ & $\begin{array}{c}\text { Ekstrak } \\
\text { pare } \\
\mathbf{1 m g} / \mathbf{m L}\end{array}$ & $\begin{array}{c}\text { Ekstrak } \\
\text { pare } \\
\mathbf{2 m g} / \mathbf{m L}\end{array}$ \\
\hline 1/2 jam & $0,00 \%$ & $0,00 \%$ & $0,00 \%$ & $0,00 \%$ & $18,33 \%$ & $19,17 \%$ \\
1 jam & $100,00 \%$ & $0,00 \%$ & $2,50 \%$ & $5,83 \%$ & $45,83 \%$ & $53,33 \%$ \\
1,5 jam & & $1,67 \%$ & $11,67 \%$ & $26,67 \%$ & $64,17 \%$ & $79,17 \%$ \\
2 jam & & $1,67 \%$ & $30,00 \%$ & $30,00 \%$ & $70,00 \%$ & $86,67 \%$ \\
3 jam & & $1,67 \%$ & $40,83 \%$ & $76,67 \%$ & $75,83 \%$ & $90,83 \%$ \\
4 jam & & $4,17 \%$ & $45,83 \%$ & $80,83 \%$ & $81,67 \%$ & $98,33 \%$ \\
5 jam & & $4,17 \%$ & $48,33 \%$ & $85,83 \%$ & $82,50 \%$ & $100,00 \%$ \\
10 jam & & $60,83 \%$ & $48,33 \%$ & $86,67 \%$ & $87,50 \%$ & \\
20 jam & & $68,33 \%$ & $72,50 \%$ & $86,67 \%$ & $91,67 \%$ & \\
24 jam & & $70,83 \%$ & $78,33 \%$ & $94,17 \%$ & $100,00 \%$ & \\
26 jam & & $72,50 \%$ & $79,17 \%$ & $95,00 \%$ & & \\
28 jam & $72,50 \%$ & $83,33 \%$ & $95,83 \%$ & & \\
30 jam & $75,00 \%$ & $84,17 \%$ & $96,67 \%$ & & \\
35 jam & $77,50 \%$ & $88,33 \%$ & $96,67 \%$ & & \\
48 jam & & $80,00 \%$ & $94,17 \%$ & $97,50 \%$ & & \\
\hline
\end{tabular}

Data yang telah diperoleh dari hasil penelitian dihitung menggunakan kurva regresi linier untuk mengetahui nilai Lethal Concentration $50 \quad\left(\mathrm{LC}_{50}\right)$ seperti yang terdapat pada Tabel 2. LC $_{50}$ merupakan konsentrasi yang mampu membunuh $50 \%$ dari total jumlah larva uji. 
Tabel 2. Nilai $\mathrm{LC}_{50}$ larva Aedes aegypti pada berbagai waktu pengamatan.

\begin{tabular}{|c|c|}
\hline Waktu (jam) & $\mathrm{LC}_{50}(\mathrm{mg} / \mathrm{mL})$ \\
\hline 0,5 & 4,46 \\
\hline 1 & 1,69 \\
\hline 1,5 & 1,10 \\
\hline 2 & 0,95 \\
\hline 3 & 0,70 \\
\hline 4 & 0,61 \\
\hline 5 & 0,57 \\
\hline 10 & 0,26 \\
\hline 20 & 0,16 \\
\hline 24 & 0,13 \\
\hline 26 & 0,14 \\
\hline 28 & 0,14 \\
\hline 30 & 0,14 \\
\hline 35 & 0,13 \\
\hline 48 & 0,11 \\
\hline
\end{tabular}

Dalam penelitian ini digunakan berbagai konsentrasi dari ekstrak buah pare yang telah diuji pada masing-masing kelompok larva. Kematian larva uji bertambah seiring dengan bertambahnya konsentrasi dan waktu. Hal ini membuktikan bahwa semakin tinggi konsentrasi dan semakin lama pajanan waktu maka semakin tinggi juga kematian larva. Aktivitas larvasida ekstrak metanol buah pare ini lebih rendah dibanding penggunaan abate $10 \%$. Abate bersifat anti cholinesterase, yang bekerja dengan mengikat enzim cholinesterase sehingga menimbukan terjadinya kontraksi otot terus menerus yang menyebabkan kematian larva (Ridha dan Nisa, 2011), sedangkan mekanisme kerja aktivitas larvasida dari ekstrak metanol buah pare belum diketahui.

\section{KESIMPULAN DAN SARAN}

\section{Kesimpulan}

Ekstrak kasar buah pare telah berhasil diekstrak dengan menggunakan pelarut metanol. Berdasarkan pengujian, sampel ekstrak metanol buah pare memiliki aktivitas larvasida terhadap larva Aedes aegypti. Nilai $\mathrm{LC}_{50}$ ekstrak buah pare sebagai larvasida berbeda untuk tiap waktu pajanan.

\section{Saran}

1. Perlu dilakukan fraksinasi dan pemurnian untuk mendapatkan senyawa aktif yang terdapat dalam buah pare sebagai larvasida

2. Perlu dilakukan uji larvasida terhadap larva yang resisten terhadap insektisida yang sering dipakai misalnya resisten terhadap abate.

3. Perlu dipelajari mekanisme kerja larvasida ekstrak metanol buah pare.

\section{UCAPAN TERIMA KASIH}

Terima kasih diucapkan pada pada DIPA UNSRI melalui skim penelitian SATEKS tahun 2012 yang telah mendanai penelitian ini.

\section{DAFTAR PUSTAKA}

Dinas Kesehatan Kota Palembang, 2012, Profil kesehatan kota Palembang 2012. Sumatera Selatan.

Kementerian Kesehatan Republik Indonesia, 2012, Profil pengendalian penyakit dan penyehatan lingkungan. Dirjend. P2\&PL, Jakarta

Li, Q.Y., Liang, H., Wang, B., and Zhao, Y.Y., 2009. Chemical constituents of Momordica charantia L., Yao Xue Xиe Bao., 44(9): 1014-1018. 
Li, T., Ling, A.P., Koh, R.Y., Chve, S.M., Voon, K.G., 2012., Screening of antidengue activity in methanolic extracts of medicinal plants, $B M C$ Complement. Altern. Med. 12:3.

Natadisastra, D dan Agus, R. 2009. Parasitologi kedokteran ditinjau dari organ tubuh yang diserang. EGC. Jakarta.

Popovitch, D.G., Li, L., Zhang, W., 2010, Bitter melon (Momordica charantia) triterpenoid extract reduces preadipocyte viability, lipid accumulation, and adiponectin expression in 3 T3-L1 cells, Food Chem, Toxicol. 48(6); 1619-1626.

Rahuman, A.A. and Venkatesan, P., 2008. Larvacidal efficacy of five cucurbitaceous plant leaf extracts against mosquito species, Parasitol. Res. 103(1); 133-139.
Ridha , M.R. dan Nisa, K. 2011. Larva Aedes aegypti sudah toleran terhadap Temepos di kota Banjarbaru, Kalimantan Selatan. E-Jurnal B2P2 VRP Salatiga, Vol 3, No.2.

Tamza, R.B., Suhartono, Dharminto, 2013, Hubungan faktor lingkungan dan perilaku dengan kejadian demam berdarah dengue (DBD) di wilayah kelurahan perumnas Way Halim Kota Bandar Lampung, Jurnal kesehatan Masyarakat, Vol 2, Nomor 3.

Yen, P.H., Dung, P.H., Nhiem, N.X., Anh Hie T., Hang, D.T., Yen, D.T., Cuc, N.T., Ban, N.K., Van-Minh, C., Van Kiem, P., 2014, Cucurbitane-type triterpen glycosides from the fruits of Momordica charantia, Nat. Prod. Commun. 9(3): 383-386. 